\title{
A IMIGRAÇÃO ESLAVA EM FILMES ARGENTINOS E BRASILEIROS
}

\author{
La Inmigración Eslava en Films Argentinos y Brasileños
}

\author{
Valdir OLIVO JÚNIOR \\ Universidade Estadual do Centro-Oeste do Paraná \\ valdir.olivo@gmail.com \\ https://orcid.org/0000-0001-9620-8081
}

RESUMO: Argentina e Brasil estão entre os países latino-americanos que mais receberam imigrantes eslavos entre o final do século XIX e início do século XX. O objetivo deste trabalho é refletir sobre como as narrativas acerca da imigração eslava foram elaboradas por alguns cineastas argentinos e brasileiros, descendentes de imigrantes eslavos. Conformam o corpus central deste trabalho os filmes: Los gauchos judios (1975) dirigido por Juan José Jusid (1941), Carta a un padre (2013) dirigido por Edgardo Cozarinsky (1939) e a trilogia da imigração ucraniana no Paraná dirigida por Guto Pasko: Made In Ucrânia - Os Ucranianos no Paraná (2006), Iván (2015) e Entre nós, o estranho (2017). A ficção aqui se instaura na fratura dos indivíduos, mas também nos arquivos e nos sentidos. Esses indivíduos fraturados que surgem na tela, estão marcados por diversas formas de violências advindas de seus países originários, do exílio e das tentativas de adaptação a um contexto inóspito. A reelaboração das narrativas da imigração pelos herdeiros dos primeiros imigrantes eslavos no contexto dos dois países nos mostra, entre outras coisas, as especificidades que a imigração assumiu em cada país e as diferentes propostas de cada cineasta para lidar com a herança cultural e histórica recebida. PALAVRAS-CHAVE: Cinema; Memória; Imigração; Exílio.

RESUMEN: En Latinoamérica, Argentina y Brasil son los países que más recibieron inmigrantes eslavos entre fines del siglo XIX y principios del XX. El objetivo de este artículo es reflexionar acerca de la elaboración cinematográfica de lasnarrativas de la inmigración eslava hechas por algunos cineastas argentinos y brasileños. El corpus de este estudio está compuesto por los films: Los gauchos judíos (1975) dirigido por Juan José Jusid (1941), Carta a un padre (2013) dirigido por Edgardo Cozarinsky (1939) y la trilogía de la inmigración ucraniana dirigida por Guto Pasko: Made In Ucrânia - Os Ucranianos no Paraná (2006), Iván (2015) e Entre nós, o estranho (2017). La ficción se instala en la fractura de los individuos, pero también en los archivos y sentidos. Los individuos fracturados que surgen en la pantalla, se encuentran marcados por diferentes formas de violencia provenientes de sus países de origen, del exilio y de los intentos de adaptación 
a un contexto inhóspito. La elaboración de las narrativas de la inmigración hecha por los cineastas nos enseña, entre tantas cosas, las especificidades que la inmigración asume en cada país y las diferentes propuestas de cada cineasta para trabajar con la herencia cultural e histórica recibida. PALABRAS CLAVES: Cine; Memoria; Inmigración; Exilio.

\section{INTRODUÇÃO}

Pensar os rastros da herança eslava em filmes feitos por descendentes de imigrantes eslavos latino-americanos é pensar o exílio. Não se trata apenas do exílio enquanto expulsão, mas sim como aquilo que se encontra fora de uma suposta ordem pré-estabelecida. $\mathrm{O}$ estrangeiro, o imigrante, é aquele que se encontra fora $(e x)$ de uma ordem pré-definida, com a qual estabelece uma relação ambivalente de integração e separação. Na violência do exílio, a destruição pode tanto aplicar-se a si mesmo, como abismo patológico da depressão e do luto interminável, como servir de energia criativa e experiência na constituição de um olhar privilegiado diante do mundo que se faz através do escrever e do filmar. "Creo que una persona feliz no escribe, que el impulso de crear existe para suplir una falta", afirma o escritor e cineasta argentino Edgardo Cozarinsky (2002). Falta que, entre suas várias acepções, encontra-se a dívida para com uma herança, traço que atravessa todos os filmes tratados aqui. Tanto Los gauchos judios (1975) dirigido por Juan José Jusid (1941) (e o mesmo podemos dizer do romance homônimo que dá origem ao filme, de 1910), quanto Carta a un padre (2013) dirigido por Edgardo Cozarinsky (1939) e também os filmes que compõem a trilogia ucraniano-brasileira de Guto Pasko (Made In Ucrânia - Os Ucranianos no Paraná (2006), Iván (2015) e Entre nós, o estranho (2017)) buscam revisitar os arquivos, muitas vezes reprimidos, do processo de imigração dos povos eslavos e inventariar os "restos" desse passado.

\section{IMAGEN(S) ESLAVAS: ARGENTINA E BRASIL}

Ainda que a busca por desencriptar os arquivos da herança histórica, cultura e pessoal do passado eslavos seja uma constante em todos os filmes aqui tratados, a forma como cada um deles opera difere substancialmente. No caso argentino, Los gauchos judios e Carta a un padre compartilham um mesmo contexto histórico, trata-se do início da colonização eslava no país. Um expressivo contingente de judeus eslavos, em sua maior parte vindos da Europa Oriental (região correspondente a Ucrânia hoje), chegou na Argentina nos últimos 
anos do século XIX. É o caso da história familiar de Edgardo Cozarinsky nascido em 1939 na cidade de Buenos Aires. Filho de Mirón Cozarinsky, marinheiro a serviço da marinha argentina e Sara Novick, ambos filhos de imigrantes eslavos judeus. Seus avós, vindos da Governação Mohine na região de Minsk, embarcaram em Odessa (Ucrânia) e desembarcaram em Buenos Aires no dia 12 de setembro de 1894. Instalaram-se na província de Entre Ríos, na cidade Villa Clara, departamento de Villaguay. Eles fizeram parte do movimento de colonização judaica que começou na Argentina em $1892 \mathrm{com}$ a compra de 80.200 hectares de terra pelo barão Maurice Hirsch. Terra, que foi distribuída entre as famílias recém-chegadas. Esses imigrantes ficaram conhecidos no país como gauchos judíos, principalmente após a publicação do livro Los gauchos judíos (1910) de Alberto Gerchunoff, no qual o escritor relata os primeiros anos da colonização judaica na província de Entre Ríos. É, portanto, o livro de Gerchunoff que serve de matéria prima para o filme de Juan José Jusid.

Ainda que o filme de Jusid preserve muitos elementos do livro de Gerchunoff, entre eles o tom jocoso e o caráter episódico, o filme prefere rearranjar a distribuição dos capítulos dando à história novas possibilidade de interpretação. Talvez a mais interessante nesse sentido seja a escolha de finalizar o filme com a adaptação do capítulo "Las bodas de Camacho" que conta a história de Raquel, que é prometida em casamento ao jovem e rico Pascual Liske (ambos imigrantes judeus), mas que é apaixona pelo gaúcho argentino Gabriel, com quem foge durante a festa de casamento. O título deste capítulo é uma referência direta a El ingenioso hidalgo Don Quijote de Miguel de Cervantes, mais especificamente à história das "bodas de Camacho", narrada nos capítulos XX e XXI da segunda parte do romance ${ }^{1}$. No entanto, a fábula de Gerchunoff pressupõe uma saída muito mais honrosa ao amante que, em lugar dos artifícios de Basílio para enganar Camacho na história de Cervantes, prefere raptar diretamente a esposa recém-casada. Mas o filme preserva o final harmônico e quixotesco de Cervantes já que tudo se resolve amigavelmente graças ao açougueiro Rajil que apazigua a multidão informando que, conforme os preceitos religiosos judaicos, a fuga só seria uma traição se acontecesse um dia após o casamento.

\footnotetext{
${ }^{1}$ Em tais capítulos, narra-se a história do triângulo amoroso entre Quiteria, prometida ao rico Camacho, mas que é apaixonada pelo pobre Basilio. No dia do casamento, a igreja é invadida por Basilio que, aos gritos, suplica a mão de sua amada e promete suicidar-se diante de todos, caso seu pedido não seja atendido. Como suas súplicas não são ouvidas, crava-se uma espada e, enquanto agoniza, pede como último gesto de misericórdia, que lhe seja concedida a honra de casar-se com Quiteria antes de morrer. Comovido com a situação, o pedido é atendido pelo padre. No entanto, finalizada a nova cerimônia, Basilio confessa que tudo foi apenas uma encenação para conseguir casar-se com Quiteria.
} 
Para além da anedota narrada, é importante indagar os motivos que levaram a Jusid a finalizar seu filme com esse capítulo que se encontra no meio do livro de Gerchunoff.

A história da colonização judaica narrada no filme de Jusid não se encontra muito longe daquilo que caracteriza, pelo menos como traço mais geral, a epopeia. É bastante visível na narrativa o caráter de viagem iniciática que representa para a comunidade judaica esse estabelecimento na Argentina. O filme começa com a chegada dos imigrantes de trem, passando pelas muitas e diferentes provações e enfretamento até chegar de fato na incorporação dos judeus eslavos na cultura argentina. Esse processo se acentua e se evidencia de diferentes formas no decorrer da narrativa, tanto no que se refere aos costumes quanto à língua. No filme de Jusid, os judeus eslavos vão de uma fase inicial na qual "nada sabíamos do campo" até sua transformação (passando por diversas provações) em "judeus gaúchos". Dessa forma, não se trata simplesmente da destruição de uma cultura em favor de outra, mas de um jogo de forças e adaptações entre elas. Ainda que esse movimento não seja, de forma alguma, pacífico. O título do livro e do filme já deixam claro que este é o objetivo das narrativas, ou seja, a mescla das culturas e o nascimento de uma nova. E é justamente esse sentimento que move o capítulo das bodas de Camacho com o qual Jusid termina seu filme. Ou seja, nada mais alegórico do que essa fuga da personagem Raquel que, por amor, escolhe um marido argentino e foge na garupa de seu cavalo rumo à imensidade da pampa argentina. Essa fuga aponta para uma concepção de união entre as duas culturas e o nascimento de uma nova era.

A publicação de Los gauchos judíos, em 1910, se dá no contexto das comemorações do centenário da independência argentina. Para entender o contexto das discussões que se espalham pela Argentina nesse momento é importante retornar aos últimos acontecimentos do século anterior no que se refere às políticas de migração adotadas principalmente pelo então presidente Domingos F. Sarmiento (1811-1888)². O roteiro da política de migração

\footnotetext{
${ }^{2}$ Escritor, militar, docente e jornalista, Sarmiento é um dos nomes mais importantes da história argentina, sua influência foi mais decisiva entre meados do século XIX e princípios do século XX. Foi presidente do país entre 1868 e 1874 e, entre outras coisas, definiu uma política de migração que impactaria drasticamente a sociedade argentina nas próximas décadas com o fomento da migração europeia. Sarmiento se exilou no Chile em 1831, após a vitória dos federalistas, conseguindo retornar à Argentina durante um curto período de tempo no ano de 1836, quando se une a um grupo de intelectuais que tece duras críticas ao governador de Buenos Aires, o caudilho Juan Manuel de Rosas. Devido a essas críticas é novamente obrigado a exilar-se no Chile em 1840, período em que escreve para muitos jornais chilenos, é em um desses jornais (El Progreso) que publica por entregas os textos que futuramente seriam reunidos sob o título Facundo o Civilización y Barbárie, livro excepcional que é, ao mesmo tempo, um tratado antropológico (alguns historiadores o consideram o primeiro do gênero no país), histórico, político e literário.
} 
de Sarmiento já se encontra desenhado em seu livro Facundo o Civilización y Barbárie (1845). Conforme o qual podemos ler (no penúltimo capítulo):

\begin{abstract}
Pero el elemento principal de orden y moralización que la República Argentina cuenta hoy es la inmigración europea, que de suyo y en el despecho de la falta de seguridad que le ofrece se agolpa de día en día en el Plata, y si hubiera un gobierno capaz de dirigir su movimiento bastaría por si sola a sanar, en diez años más, todas las heridas que han hecho a la patria los bandidos, desde Facundo hasta Rosas, que la han dominado (SARMIENTO, 2006, p. 291).
\end{abstract}

Para Sarmiento, a única forma de civilizar a Argentina era suprimindo a bárbara cultura gauchesca através do fomento da imigração europeia. Foi com essa política a favor da imigração que a Argentina deixou o século XIX. Para Sarmiento a cultura gauchesca estava atrelada a valores arcaicos e mais especificamente ao caudilhismo, cujos principais representantes eram Facundo Quiroga (1788-1835) e Juan Manuel de Rosas (17931877). Dessa forma, a imigração para Sarmiento, tem por objetivo uma europeização do país (que para ele também era significado de modernização) e, consequentemente, um gradativo apagamento da cultura originária. Foi neste momento de mudança para uma política em prol da europeização, que vai ter no governo de Sarmiento seu ponto alto, que José Hernández (1834-1886) escreveu a primeira parte de poema narrativo Martín Fierro (1872), denunciando os ultrajes pelos quais passavam os gaúchos nessa sociedade de então, obrigados a lutar nas fronteiras onde padeciam fome e maus-tratos, em uma sociedade na qual "ser gaucho es un delito" (HERNÁNDEZ, 2012, p. 160). Com Sarmiento na presidência o gaúcho será renegado e exilado e, dessa forma, irá ocupar a posição que ele outrora havia ocupado no governo de Juan Manuel de Rosas ${ }^{3}$. O poema de Hernández surge como uma antítese da obra de Sarmiento, o principal exemplo dessa contraposição está nos momentos finais do poema, quando Fierro e Cruz preferem ir viver com os índios a continuar nessa sociedade bárbara que escravizava o gaúcho.

No entanto, essa postura de José Hernández tomará novos rumos com o fim do mandato de Sarmiento. Isso ocorre na segunda parte do poema, intitulada La vuelta del gaucho Martín Fierro (1879), com a representação de um novo gaúcho em uma nova

\footnotetext{
${ }^{3}$ Vale lembrar que quando Juan Manuel de Rosas centraliza em si o poder político, muitos dos intelectuais são perseguidos e devem partir do país. É o caso, entre tantos, dos escritores Esteban Echeverría e Domingos Faustino Sarmiento exilados no Uruguai e Chile respectivamente. Facundo, em palavras de Sarmiento (2006), nasce com o intuito de mostrar ao povo chileno o que acontecia na Argentina governada por Rosas. O mesmo podemos dizer de El matadero de Echeverría (2018).
} 
sociedade. Um gaúcho resignado, que deseja voltar aos valores da família e do trabalho.

Nessa nova sociedade o papel de Hernández será de ajudar na "formação moral e ideológica do novo indivíduo", visando o bom funcionamento do aparato governamental. A nova obra de Hernández é para despertar "la inteligencia y el amor a la lectura", para servir de distração como um "provechoso recreo depués de las fatigosas tareas" (2012, p. 05). Nesse sentido, La vuelta marcaria a reinserção do gaúcho na sociedade. O último poema é a síntese das duas obras anteriores. O personagem Fierro se transforma em uma espécie de educador, como foi Domingo F. Sarmiento ${ }^{4}$.

As bipolaridades rural e urbano, capital e província, civilização e barbárie são recorrentes na literatura argentina. E é nesse contexto que se instala a publicação de Los gaúchos judios que reinvindica o papel dos judeus eslavos na consolidação da nação argentina. O livro de Gerchunoff é, dessa forma, também parte integrante do ciclo da afamada literatura gauchesca.

No entanto, no contexto das comemorações do centenário da independência há, por outro lado, uma inversão do pensamento de "civilização e barbárie" desenvolvido por Domingos F. Sarmiento. Esta civilização (que para Sarmiento estaria na cidade e na cultura europeia) é reformulada pelos novos intelectuais, encabeçados por Leopoldo Lugones (1874-1938), que se propõem estabelecer uma disputa no campo simbólico do discurso de "formação da nacionalidade" . Em uma de suas conferências por motivo do centenário, Lugones, propõem que o poema gauchesco El gaucho Martín Fierro de Hernández seja lido e considerado a epopeia nacional por excelência. A respeito da inversão da dicotomia civilização e barbárie, Carlos Altamirano no livro Ensayos argentinos (1997), escrito juntamente com Beatriz Sarlo, evocando o escritor de Fuerzas extrañas (1906), afirma:

Lugones lo señala: "Bárbaro significa revesado, tartamudo: nuestro gringo". Se trata pues de nuestro bárbaro el inmigrante. En efecto, en el curso de la primera década del siglo XX había ido tomando forma-

\footnotetext{
${ }^{4}$ Destaca-se na Argentina o papel de Sarmiento no que se refere ao desenvolvimento educacional do país. Sarmiento contribuiu com diversas políticas públicas e com a criação de escolas pelo país. Em 1849 ele escreve o livro Educación popular um dos marcos do que seria a futura Ley de Educación Común.

${ }^{5}$ Entendo tal discurso a partir das reflexões de Angel Rama (1984, p. 74) em La ciudad letrada: "La constitución de las literaturas nacionales que se cumple a fines del XIX es un triunfo de la ciudad letrada, la cual por primera vez en su larga historia, comienza a dominar a su contorno. Absorbe múltiples aportes rurales, insertándolos en su proyecto y articulándolos con otros para componer un discurso autónomo que explica la formación de la nacionalidad y establece admirativamente sus valores."
} 
paralela a la imagen ya consolidada de la inmigración como "agente de prosperidad"- de que constituía un factor anárquico y disolvente para la convivencia social. Esa certidumbre brotó y halló eco sobre todo entre los miembros de la elite de "viejos criollos" y de allí surgió también el movimiento dirigido a dotar la figura del gaucho de una nueva función cultural. Es decir, no ya tema de evocación nostálgica, sino elemento activo de identificación: "Todo cuanto es propiamente nacional viene de él", dita Lugones en "El payador". (ALTAMIRANO; SARLO, 1997, p. 205)

Dessa forma, Los gauchos judios de Gerchunoff é, por um lado, uma resposta às mudanças das políticas migratórias da Argentina no início do século XX e, por outro, uma tentativa de inserir os judeus eslavos como parte integrante do discurso de nacionalidade, afirmando assim seu lugar na formação do país. No decorrer das décadas posteriores, o livro de Gerchunoff passa a conformar o canon da literatura nacional. No entanto, isso não significa que o antissemitismo não possua raízes profundas na Argentina, ele fica mais evidente quando lembramos alguns dos acontecimentos que envolveram as filmagens e exibições do filme entre 1974 e 197, quando a Argentina se encontrava na antessala de sua mais sanguinária ditadura (que se instalaria definitivamente no ano seguinte). Entre os acontecimentos que envolveram as filmagens e exibições do filme, Federica Rocco (2015), nos recorda: o incômodo que causou a López Rega (fundador da Triple A) ${ }^{6}$ a junção das palavras "gaúcho e judeu", o incêndio criminoso da cidade criada para as filmagens, a censura de Paulino Tato que proibiu sequências inteiras do filme, ameaças de bomba e a concretização da ameaça com a explosão de uma bomba incendiária em uma das salas de cinema, entre outros atentados.

Sendo assim as condições históricas que envolveram as filmagens e exibições de Los gauchos judios, ainda que muito mais dramáticas, se assemelham às da publicação do livro já que corresponde a uma radicalização de movimentos nacionalistas e fascistas que ganhariam força nos meses seguintes até culminarem no golpe de estado de 1976.

No entanto, mesmo diante de um contexto extremamente inóspito, tanto no

\footnotetext{
${ }^{6}$ José López Rega (1916-1989) assumiu o cargo de Ministro do Bem-Estar Social no governo de Héctor Cámpora, em 1973, se mantendo na função durante os governos de Juan Domingo Perón e Maria Estela Martínez (Isabel Perón), entre 1973 e 1975. Ainda em 1973 López Rega, também conhecido como El Brujo, cria a Triple A (Alianza Anticomunista Argentina), grupo paramilitar de perseguição e extermínio de pessoas considerados de esquerda. López Rega ganha mais força durante o governo de Isabel, após a morte de Perón, assumindo a maior parte das decisões políticas do país no período prévio ao golpe militar de 1976. A Triple A seria extinta após o golpe de estado de 1976 e o papel que desempenhava passou a ser incumbência do exército argentino.
} 
livro quanto no filme prevalece uma visão idílica da imigração judaica; os conflitos, a violência e desavenças gerados com os insatisfeitos com a colonização, e também pelo antissemitismo, são apaziguados em ambos os textos pelo tom jocoso que harmoniza os conflitos e a violência para com os imigrantes. Dessa forma, faz-se necessário ler livro e filme para além do que é narrado (fábula), buscando reconhecer as engrenagens da máquina narrativa, ou seja, a ficção como sendo a trama das relações estabelecidas através do discurso, conforme nos adverte Michel Foucault. ${ }^{7}$

No caso de Carta a un padre de Edgardo Cozarinsky, o tom intimista é ainda mais evidente do que no livro de Gerchunoff. A reescritura do passado familiar é recorrente na literatura e no cinema de Edgardo. Trata-se de um trabalho de reconstituição da herança literária e familiar. É justamente para fugir do antissemitismo que os avós de Cozarinsky se mudam para a Argentina. Parte dessa história é recuperada por Cozarinsky em Carta a un padre $(2013)^{8}$. No filme, Cozarinsky lembraria ainda que o antissemitismo nunca foi algo alheio à Argentina, pelo contrário, são diversos os ataques antissemitas na Argentina. Entre eles, talvez o mais famoso seja a Semana Trágica de 1919 que Cozarinsky chama de "pogrom portenho" (COZARINSKY, 2013, p. 30).

Em uma sequência de Carta a un padre, vemos o cineasta diante da tumba de seu avô, lendo comovido a carta que Abraham escreveu para seu filho, Mirón Cozarinsky, quando este conta seus planos de viajar aos Estados Unidos. Neste momento, a "cartafilme" de Edgardo e a carta de seu avô se misturam e talvez seja o momento mais evidente no filme de que o passado nunca passa. O passado do pai e do avô seguem ativos: "Como yo hice un viaje fluvial por la gran Rusia, sé que todo lo que uno puede ver viajando para siempre queda grabado en el corazón de uno para toda la vida". A comoção de Cozarinsky talvez não seja apenas pelo afeto por um avô que ele não pôde conhecer, já que faleceu em 1934, mas sim por esse exercício de necromancia no qual o avô se levanta de sua tumba

\footnotetext{
${ }^{7}$ Em 1963, Michel Foucault (1994, p. 280) definia a ficção como "la nervure verbale de ce qui n'existe pas, tel qu'il est." O que Foucault propunha neste artigo, intitulado "Distance, aspect, origine", era justamente a literatura não mais como retórica, mas sim como rede de linguagem na qual o fictício seria um afastamento da linguagem que, ao mesmo tempo, a expõe, dispersa e abre. Já em 1966, no artigo "L'arrière-fable" Foucault dava um passo além em sua leitura e propunha a distinção entre fábula e ficção. Enquanto a fábula se identifica com o que é contado, a ficção é a trama das relações estabelecidas através do discurso. Ou seja, a diferença está entre o que é narrado (fábula) e a máquina narrativa (ficção).

${ }^{8}$ Cozarinsky vai a Entre Ríos em busca da história de seu pai que faleceu quando ele ainda era jovem. O filme é, para ele, uma forma de saldar uma dívida com seu pai: "Mi padre murió cuando yo tenía veinte años. Todavía estaba en medio de una adolescencia demorada y no le presté mucha atención; es una deuda pendiente que me quedó.” (COZARINSKY, 2012).
} 
para falar com o neto, mas também de alguma forma do neto, que até hoje vive entre dois continentes, jogando com "imagens próprias e alheias"9.

Como afirma Cozarinsky, em entrevista de 2012, o filme é uma forma de pagar uma dívida para com seu pai e sua experiência com o judaísmo, mas trata-se, sobretudo, de uma dívida que nunca termina. Pois a excripta ${ }^{10}$ de Edgardo conjuga ao mesmo tempo a existência, a escritura, o exílio e a cripta, ou seja, ela carrega consigo e em si os espectros de seus mortos. O luto é sempre uma dívida em relação a uma herança. Isso nos remonta ao conceito de "obediência a posteriori" de Freud, segundo o qual, o pai morto torna-se mais forte do que foi enquanto vivo ${ }^{11}$. No entanto, o trabalho de luto não é a superação daquilo que foi perdido, mas sim, como nos ensina o filme, a encriptação do morto no vivo.

O exílio enquanto problemática é facilmente detectável nos textos do escritor argentino. É assinalado por Susan Sontag e Cabrera Infante nos prólogos que antecedem Vudú urbano $(1985)^{12}$, seu primeiro livro publicado. No entanto, em minhas pesquisas ${ }^{13}$, descobri que o exílio não é apenas uma temática que surge como resultado do exílio de Cozarinsky na França, em 1974, mas sim a engrenagem principal de uma concepção literária que começa a se formar ainda em sua juventude, em suas primeiras publicações jornalísticas (em sua maior parte resenhas literárias e cinematográficas). O exílio em Cozarinsky é singular-plural, configura-se principalmente a partir de uma herança familiar, literária e cinematográfica. Não é uma mera temática, mas uma estratégia textual, trata-se do exílio como escrita que desloca, inverte e decompõem textos da cultura recompondoos provisoriamente a partir de suas ruinas ${ }^{14}$.

\footnotetext{
${ }^{9}$ Carta a un padre.

${ }^{10}$ Desenvolvo mais sistematicamente o conceito de excripta em minha tese: OLIVO JÚNIOR, 2015.
}

11 "O morto tornou-se mais forte do que havia sido o vivo [...] Aquilo que antes ele impedira com sua existência eles proibiram então a si mesmos, na situação psíquica da "obediência $a$ posteriori", tão conhecida nas psicanálises" (FREUD, 2015, p. 141).

${ }^{12}$ Os títulos são, respectivamente, "La cosmopolis del exiliado" e "Notes inegales".

${ }^{13}$ Nesse sentido busquei fazer uma compilação sistemática de suas primeiras publicações, ignoradas até então pela crítica e pelo próprio autor.

${ }^{14} \mathrm{O}$ leitor perceberá aqui as similaridades com a déconstruction do filósofo franco-argelino Jacques Derrida. Aprofundo essas relações em minha tese, mais detidamente nos capítulos 4, 5 e 6 (OLIVO JÚNIOR, 2015). 
Da mesma forma, essa dívida de Cozarinsky com o passado perdido de seu pai, poderia muito bem-estar atrelada a esse "desejo de genealogia" e sobrevivência tão presentes em seus textos. Essa preocupação de Edgardo para com as sobrevivências se manifesta frequentemente em sua obra e ressoaria de forma bastante objetiva em Carta a un padre (2013) pela voz e tradução de Edgardo de uma citação de Georges Perec: "Trato de hacer que algo sobreviva. Quisiera arrebatarle unos pocos fragmentos al vacío que crece, dejar en alguna parte un surco, una huella, una marca, aunque sólo sea unos pocos signos." $" 15$

Ao assumir o exílio como parte integrante da própria existência e como estratégia textual, Cozarinsky opera profanando arquivos, conceitos e textos que compõem a cultura, desmontando-os para, em seguida, montá-los de outra forma, gerando um estranhamento onde antes as relações e conexões pareciam familiares e acabadas dando lugar às marcas de uma herança diferida que se imprime no nome "Cozarinsky" que originalmente era escrito com "s" e não com "z". Dessa forma, se Los gauchos judios de Jusid busca uma integração ao sentimento de nacionalidade argentino, mesmo diante da fratura e da violência que palpita no extracampo das imagens, Cozarinsky opta por ressaltar a fratura e o deslocamento como lugar do filho imigrante:

Quiero agregar que si en esa tierra que llaman la patria está el padre, y en la lengua es la madre quien opera, en estos gestos de la escritura, de la lectura, de traducciones enfrentadas en los espejos deformantes de varios idiomas, el exilio del que se habla y que habla es del hijo. (COZARINSKY, 2007, p. 163-4).

E o lugar do cinema de temática eslava no Brasil e na Argentina é o do filho. Os filhos são os responsáveis pela ruptura com os moldes de uma cultura originária e, ao mesmo tempo, pelo desejo de retorno ao passado familiar. Um retorno atravessado pelas experiências de uma dupla origem e cultura.

No Brasil, Guto Pasko é quem mais se dedicou até o momento em reconstruir cinematograficamente a herança de imigração eslava tendo como o foco as regiões centro-sul e metropolitana do Paraná. Seus trabalhos mais contundentes nesse sentido são os filmes que compõem a trilogia ucraniana, formada pelos filmes Made In Ucrânia - Os Ucranianos no Paraná (2006), Iván (2015) e Entre nós, o estranho (2017). Em Made in Ucrânia, Guto Pasko inicia sua abordagem da imigração ucraniana no interior

\footnotetext{
${ }^{15}$ A citação é feita por Cozarinsky no filme e encontra-se no livro Especies de espacios (PEREC, 2001, p. 140).
} 
do Paraná de forma didática, fazendo uso de um documentário investigativo clássico que busca narrar e historicizar o estabelecimento das comunidades eslavas no país. Aborda os bastidores históricos que levaram a saída dos ucranianos da Europa e também as políticas nacionais que incentivaram a imigração, mas que não cumpriram as promessas realizadas. O filme Iván se propõe a narrar a história de Iván Bojko, segue na mesma linha do filme anterior, ou seja, trata-se também de um documentário com um propósito investigativo, no entanto, agora também biográfico. O contato de Guto Pasko com Iván, protagonista do filme, aconteceu no filme anterior no qual Iván é apresentado como imigrante ucraniano que, ao chegar no Brasil, assume como profissão a construção de banduras ${ }^{16}$.

Iván, no entanto, é um filme que vai muito além da mera curiosidade biográfica. No decorrer da narrativa, Ivan se mostra muito mais do que um artesão. É quando sabemos, entre tantas coisas, que ele foi um soldado nacionalista, sequestrado pelos nazistas e condenado a trabalhos forçados, e que após o fim da segunda guerra não foi aceito pelos soviéticos, que controlavam a Ucrânia, exilando-se então no Brasil. O filme se divide entre Curitiba e Ucrânia, com a inesperada visita de Iván a sua terra natal. Já Entre nós, o estranho é um documentário etnográfico que, diferentes dos demais, centrase unicamente na cidade de Prudentópolis localizada na região centro-sul do Paraná. Se nos dois primeiros filmes temos a participação e intervenção direta de Guto Pasko que interage com os participantes do filme, em Entre nós não há nenhuma intervenção direta do diretor na diegese fílmica. O filme não possui narrativa ou possui uma narrativa mínima, é através da relação e do choque entre imagens que se constroem significações.

Como no caso argentino, os filmes de Guto Pasko também saldam uma dívida para com uma herança familiar. Ainda na juventude, Guto Pasko rompe com as tradições familiares rígidas que haviam premeditado seu destino como padre e se muda para a capital do estado cortando laços com a família. No entanto, com o passar dos anos, o peso da herança familiar e cultural se tornou inevitável. A trilogia de Gusto Pasko é também a história dessa reaproximação familiar, cultural e identitária. Diferente dos filmes argentinos que potencializam o deslocamento e a ficção, instaurando fraturas em indivíduos, arquivos e sentidos, inicialmente ao menos, sobressai nos filmes de Guto um desejo de completude, integração e a busca por uma verdade histórica. Isso fica evidente em Made in Ucrania, filme no qual a voz do diretor busca rigorosamente seguir seus

\footnotetext{
${ }^{16}$ Bandura é um instrumento de corda tradicionalmente ucraniano. Possui certas semelhanças com a cítara, o alaúde e a kobza. Há uma grande variação na quantidade de cordas da bandura que pode ir de 20 a mais de 60 . Existe na Ucrânia uma tradição de tocadores cegos de bandura que remonta ao século XVII, eram bardos itinerantes chamados kobzares.
} 
objetivos didáticos. Até por isso, talvez, a figura de Iván seja ainda mais importante para Guto do que se poderia pensar inicialmente. Iván exige ser algo mais do que um documento entre muitos ou uma voz-testemunho em um filme que persegue um desejo de discurso histórico. Iván marca essa transformação no cinema de Guto, na qual o desejo de perseguir uma completude historiográfica é substituído pelas potencialidades ficcionais, narrativas e imagéticas proporcionadas pelo personagem. Ou seja, Iván evoca a potencialidade do micro perante o macro. Ainda que o segundo filme da trilogia seja também um documentário, ela não almeja a História (com maiúscula), mas a micro-história de Ivan. Como demonstrou Carlo Ginzburg através do conceito de micro-história (2006), um indivíduo pode servir de microcosmo para refletir sobre as relações entre diferentes forças históricas de um determinado período. Já não se trata de adequar a narrativa fílmica a uma trilha precisa do discurso histórico, mas tatear pelas suas margens, evocando a espectralidade de um passado que, ainda que fragmentado, não deixa de assombrar o personagem e a nós espectadores. Esse passado oculto é evocado por Iván que busca revirar as camadas subterrâneas que compõem a realidade cotidiana dos personagens.

Talvez um dos momentos mais interessantes do filme no que se refere a essa evocação do passado seja durante a viagem de Iván. Já em solo ucraniano, de dentro do ônibus que trafega rumo a sua aldeia natal, Iván assume o lugar de guia, orientando a todos (inclusive o motorista) a partir de um mapa previamente rascunhado com o próprio punho. Iván busca guiar seus companheiros de viagem pelas ruas e avenidas da Ucrânia presente, mas também pelas camadas de passado encobertas sob a epiderme da modernização e de uma paz aparente. Mais do que a paisagem e suas transformações advindas dos vinte anos passados desde sua chegada ao Brasil, o que vemos a partir dos olhos de Iván é uma Ucrânia de sua juventude, interrompida pela invasão dos alemães e, posteriormente, pelos soviéticos. Após a chegada na aldeia natal, o telão da paisagem idílica que envolve os personagens vai cedendo aos poucos e dando lugar a um cenário sombrio de perseguições e execuções. Próximo às ruinas da casa da infância (construída pelas mãos de seu pai), após relembrar o processo de construção da casa, Iván se dirige ao redor e diz: "mudou tudo, aqui tinha uma pequena floresta; ainda tem um pouco venham ver". No entanto, é sua sobrinha quem interrompe as nostálgicas recordações de infância ao dizer: "eu contava sobre aqueles quinze jovens da guerrilha que foram fuzilados aqui". A face de Iván, antes comovida diante das lembranças, toma a forma enérgica de revolta e pergunta: "O quê? Fuzilaram quinze jovens nacionalistas aqui? " Não se trata apenas de uma confirmação, mas também uma correção, Iván corrige a palavra genérica "guerrilha" trocando-a por "nacionalistas". De volta a sua terra, Iván reassume seu lugar como defensor da soberana ucraniana que o levou aos trabalhos forçados e a impossibilidade de 
retorno ao país dominado pelos soviéticos.

A narrativa idílica do retorno ao passado é constantemente fraturada pelos espectros da violência que rondam a história de Iván e a história ucraniana. A narrativa do diretor e a narrativa do protagonista assumem uma relação que não é tão previsível quanto a estrutura do documentário tradicional parece sugerir. Se, por um lado, Iván sabe que será parte de uma narrativa alheia, controlada pelas intervenções e montagem da equipe liderada por Guto, por outro lado, ao ter consciência deste papel assume-o impelindo a narrativa para os seus próprios domínios. A argúcia e a rebeldia de Iván, reacendida pelo retorno à pátria, o impele também a potencializar sua transformação em agente simbólico. Iván, indivíduo fraturado histórica e fisicamente, assume seu lugar como símbolo nacional da resiliência de um país que, mesmo após todos os infortúnios históricos, luta por manter suas tradições e sua unidade. É na igreja de sua aldeia natal que Iván profere seu discurso, conclamando o respeito ao próximo e a união entre todos pela defesa da Ucrânia, em seguida, ressalta seu lugar simbólico na pátria revisitada: "nós temos dez dedos. Dez dedos é uma potência... na mão. Potência! Quando vocês perdem um ou dois dedos, já não é mais a mesma força. Como exemplo, eu! Vejam! Falta um dedo, não tenho a mesma força! Falta força!’. Ainda que Iván se coloque como contraexemplo, não é este seu lugar na narrativa. Desde o início, ele ocupa o centro, sua micro-história almeja também o macro. A perda do indicador durante os anos de trabalhos forçados na Alemanha é a marca, a impressão da violência, que se inscreve no corpo de Iván, a mão com o dedo decepado é também metaforicamente a dilapidação do território ucraniano, fruto de constantes tensões e sequestros desde sua origem. Constante histórica que permanece, vista a repetição da amputação da Criméia, esse "dedo" apontado para a Rússia, que permanece sequestrado desde 2014. Ainda que Iván tenha perdido um dedo, ele reconstruiu a integralidade de sua mão fazendo da bandura sua prótese imaginária. É em seu exílio no Brasil que ele (que nunca antes havia construído um instrumento) começa a fabricar banduras. Sem poder resistir na luta em sua terra natal, Iván resiste culturalmente em terras brasileiras:

Eu senti a minha pátria, a bandura dá força para o povo ucraniano porque não existe tão querido instrumento e tão famosa como na Ucrânia e veja bem nossos inimigos, como maioria Rússia, eles liquidaram o instrumento ucraniano kobza, lira, bandura... eles liquidaram porque ela dá raiz para o povo. Canções históricas, música e história quando toca-se bandura então já com bandura a gente canta (...) a música é revolucionaria. Eles não gostavam porque o povo (...) sempre chamou pela música/canção para o povo não se perder, levantar. Guardar a pátria no coração. Porque sem música, sem canção é pessoa morta, não tem raiz. 
A música é a acentuação e a reverberação do inexistente. É o invisível do som que se faz visível conforme nos explica Iván, ressaltando o caráter protético e revolucionário da música.

O discurso da igreja, que acontece em meados do filme, retoma e evidencia momentos anteriores, inclusive o início, quando vemos Iván tocando bandura com sua mão lesada pela guerra enquanto canta: "Rolaram as lágrimas jovens/ garota chorando ao ver/ sumindo na mata escura / valentes heróis do porvir/ sumindo na mata escura/ valentes heróis do porvir." A música que bem poderia ser uma homenagem aos quinze jovens assassinados na floresta, ao lado de sua antiga casa, também funciona como um uma promessa de futuro. Promessa que bem poderia ser endereçada a ele mesmo, pois ainda que já não tenha as forças de que falava anteriormente, ele sabe que todo ato revolucionário passa, antes de mais nada, por um processo de construção imaginária e simbólica. Não há "heróis do porvir" sem alguém que os cante e celebre. No entanto, e apesar de tudo, Iván sabe que seu lugar não é na Ucrânia, em seu discurso na igreja ele deixa claro que "espera naquela terra [Brasil] descansar definitivamente", algo que infelizmente ocorre no dia 24 de dezembro de 2016.

Iván é um estranho, um estrangeiro no Brasil, mas também em sua terra natal. $\mathrm{O}$ seu território parece ser um território imaginário de sua infância e juventude, um país ao qual se sobrepõem camadas de passado e lembranças de outros países.

\section{CONCLUSÃO}

No decorrer deste artigo refleti sobre a elaboração cinematográfica da herança eslava brasileira e argentina, discorri acerca das semelhanças e particularidades de cada diretor no âmbito de seu país e de sua proposta estética. Nos filmes aqui tratados são os filhos e netos dos primeiros imigrantes, os responsáveis pela ruptura com os moldes de uma cultura originária e, ao mesmo tempo, pelo desejo de retorno ao passado familiar. Talvez isso ocorra porque para eles tenha se passado o tempo necessário para que as experiências traumáticas do passado tenham sido amenizadas e, dessa forma, o passado possa enfim respirar um ar catártico de possível resolução. No entanto, as diferenças e particularidades de cada filme são significativas. No caso de Los gauchos judíos de Jusid, há uma clara reinvindicação da voz eslavo-judaica na construção do discurso de nacionalidade argentino. O mesmo não podemos dizer de Carta a un padre, no qual Cozarinsky dissolve qualquer desejo de pertencimento a um território ou nacionalidade específica e potencializa a diferença. Não se trata de uma negação da herança, mas sim da valorização da experiência crítico-subjetiva do indivíduo sobre aquilo que foi recebido, 
ou seja, uma herança diferida. Já nos filmes de Guto, especialmente Iván sobre o qual nos debruçamos mais detidamente, há o desejo de reaproximação com sua cultura de origem, mas também de contar a história da imigração eslava (neste caso mais especificamente ucraniana) no Brasil.

Para além das especificidades de cada filme, o exílio é um dos fios centrais no emaranhado das narrativas aqui tratadas. Em todos os filmes há sempre uma relação de inadequação dos personagens, são estrangeiros tratando de adequar-se a uma nova cultura, mas ao mesmo tempo transformados ao ponto de se tornarem estranhos ao país e cultura de origem. O exílio é, muitas vezes, o lugar da catástrofe, do homem lançado ao caos no qual deve despojar-se de seu nome, língua e identidade. Mas o exílio também é promessa de salvação e potência, o exercício de reinventar-se ao qual nos obriga é avesso a qualquer noção de pureza ${ }^{17}$. A potência do exílio não está unicamente na saída, mas na hospitalidade para com o outro, para com tudo o que seja estranho a si mesmo.

\footnotetext{
${ }^{17}$ Em entrevista concedida a Karina Wroblewski, Cozarinsky afirma: "Creo que hoy lo que me interesa es la contaminación, me interesa todo lo que es impuro, todo lo que mezcla cosas que vienen de distintos horizontes y las hace chocar y sacar alguna chispa, es lo único que me interesa. $\mathrm{Y}$ eso tiene que ver un poco... es algo que yo evolucioné después de mi primer viaje a Europa." (COZARINSKY, 2005).
} 


\section{REFERÊNCIAS:}

ALTAMIRANO, Carlos; SARLO, Beatriz. Ensayos argentinos. De Sarmiento a la vanguardia. Buenos Aires: Ariel, 1997.

BENJAMIN, Walter. Magia e técnica, arte e política. Obras escolhidas. Tomo I. Tradução de Sérgio Paulo Rouanet. São Paulo: Brasiliense, 2008.

COZARINSKY, Edgardo. Borges en/y/ sobre cine. Madrid: Espiral, 1981.

COZARINSKY, Edgardo. Vudú urbano. Buenos Aires: Emecé, [1985] 2007.

COZARINSKY, Edgardo. Sara. Buenos Aires: Urania, 2013.

ECHEVERRÍA, Esteban. El matadero. Madrid: Editura Verbum, 2018.

FREUD, Sigmund. O Delírio e os sonhos na Gradiva, Análise da fobia de um garoto de cinco anos e outros textos. Obras Completas 1906-1909. Tradução de Paulo César de Souza. São Paulo: Companhia das Letras, 2015.

FOUCAULT, Michel. Dits et Ecrits. París: Gallimard, 1994.

GERCHUNOFF, Alberto. Los gauchos judios. Buenos Aires: Ediciones Colihue, 2007.

GUINZBURG, Carlo. O queijo e os vermes. Tradução de José Paulo Paes. São Paulo: Companhia das letras, 2006.

HERNÁNDEZ, José. El gaucho Martín Fierro; La vuelta del gaucho Martín fierro. Buenos Aires: MDA, 2012.

OLIVO JÚNIOR, Valdir. Excripta Cozarinsky. 2015. Tese em Literatura - Centro de Comunicação e Expressão, Universidade Federal de Santa Catarina, Florianópolis.

PEREC, Georges. Especies de espacios. Tradução ao espanhol de Jesús Camarero. Barcelona: Montesinos, 2001.

RAMA, Ángel. La ciudad letrada. Montevideo: Arca, 1984.

SARMIENTO, Domingos F. Facundo; Buenos Aires: Losada, 2006 


\section{Entrevistas e documentos eletrônicos:}

COZARINSKY, Edgardo. Abecedario Cozarinsky. Tijeretazos. Disponível em: $<$ http://www.tijeretazos.net/Abecedario/Cozarinsky/Cozarinsky020.htm>. Acesso em 12 maio 2020.

COZARINSKY, Edgardo. Entrevista a Edgardo Cozarinsky [Paris, 7 de dezembro de 2001]. Cuadernos Hispanoamericanos, Madrid, n. 621, p. 97-112, mar. 2002.

COZARINSKY, Edgardo. La pasión de lo desconocido. La Nación, Buenos Aires, 29 jul. 2007. Disponível em: <http://webcache.googleusercontent.com/search?q=cache:bfLrK_ Hu3GkJ:www.lanacion.com.ar/929571-la-pasion-de-lo-desconocido+cozarinsky+mi+pa dre+ejercito\&cd=1\&hl=es\&ct=clnk\&gl=es $>$. Acesso em 12 maio 2020.

COZARINSKY, Edgardo. Obra en construcción: Edgardo Cozarinsky. Audiovideoteca de Escritores, Buenos Aires. Entrevista filmada com direção de Karina Wroblewski, realizada em 2005. Disponível em: <http://www.youtube.com/watch?v=QvkUPbXCE-w>. Acesso em 04 jul. 2020.

COZARINSKY, Edgardo. Todos necesitamos cambiar de vida, reinventarnos. Página 12, Buenos Aires, publicação online datada de 25 de setembro de 2012. Entrevista concedida a Silvina Friera. Disponível em: <http:/www.pagina12.com.ar/diario/suplementos/ espectaculos/4-26540-2012-09-25.html>. Acesso em 12 maio 2020.

ROCCO, Federica. Los gauchos judíos en la literatura y el cine argentinos. Oltreoceano, Udine, v. 9, p. 211-220, 2015. Disponível em: $<$ https://riviste.forumeditrice.it/oltreoceano/ article/view/647>. Acesso em 02 jun. 2020.

\section{Filmes:}

CARTA a um padre. Direção de Edgardo Cozarinsky. Argentina, 2013. 63 minutos.

ENTRE nós, o estranho. Direção de Guto Pasko. Brasil, 2017. 83 minutos.

IVÁN. Direção de Guto Pasko. Brasil, 2011. 109 minutos.

LOS gauchos judíos. Direção de Juan José Jusid. Argentina, 1975. 110 minutos.

MADE in Ucrânia. Direção de Guto Pasko. Brasil, 2006. 102 minutos. 